\title{
Cellulose Nanofibers and Reducing Sugars from Soybean Straw: An Investigation of the Enzymatic Activity and the Biomass Concentration Effect by Response Surface Methodology
}

\section{Natalia Cristina da Silva}

Universidade de Sao Paulo Faculdade de Zootecnia e Engenharia de Alimentos

\section{Bruno Stefani Esposto}

Universidade de São Paulo Faculdade de Filosofia Ciências e Letras de Ribeirão Preto: Universidade de Sao Paulo Faculdade de Filosofia Ciencias e Letras de Ribeirao Preto

\section{Bianca Chieregato Maniglia}

Universidade de São Paulo Faculdade de Filosofia Ciências e Letras de Ribeirão Preto: Universidade de Sao Paulo Faculdade de Filosofia Ciencias e Letras de Ribeirao Preto

\section{Delia Rita Tapia-Blácido}

Universidade de São Paulo Faculdade de Filosofia Ciências e Letras de Ribeirão Preto: Universidade de Sao Paulo Faculdade de Filosofia Ciencias e Letras de Ribeirao Preto

Milena Martelli Tosi ( $\square$ mmartelli@usp.br)

Universidade de Sao Paulo Faculdade de Zootecnia e Engenharia de Alimentos https://orcid.org/0000-0001-6060-9713

\section{Research Article}

Keywords: soybean straw, lignocellulosic material, nanofibrils, reducing sugars, enzymatic hydrolysis.

Posted Date: September 20th, 2021

DOI: https://doi.org/10.21203/rs.3.rs-836093/v1

License: @ (1) This work is licensed under a Creative Commons Attribution 4.0 International License. Read Full License 


\section{Abstract}

This study investigated the effect of different conditions of enzymatic hydrolysis on the production of nanofibers and reducing sugars from soybean straw. The milled and sieved lignocellulosic biomass underwent two an alkaline pretreatment using $\mathrm{NaOH} 5 \%$ (PT1) or 17.5\% (PT2), bleaching $\left(\mathrm{H}_{2} \mathrm{O}_{2} 4 \%\right)$ and enzymatic (Optimash VR'"; Dupont, USA) treatments. The effects of the enzymatic activity and the pretreated soybean straw concentration were evaluated using a Rotational Compound Central Design (DCCR) $2^{2}$. An increase in the enzymatic activity and a decrease in the concentration of soybean in the suspension enhanced the production of sugars. This effect was due to the higher ratio of enzymatic activity/soybean straw pretreated concentration. Enzymatic activity disfavoured the nanofiber production for PT1, but favoured for PT2, probably due to the higher defibrillation when higher alkaline concentration is used. For both materials (PT1 and PT2), the lower soybean straw concentration furnished more stable suspensions. The optimal condition for the simultaneous production of reducing sugars and nanofibers was $4.0 \mathrm{~g}$ of biomass and enzymatic activity of 600 $\mathrm{CMCU}$. This study shows that soybean straw has great potential for the industrial production of cellulose nanofibers and reducing sugars due to processing efficiency and low raw material cost.

\section{Introduction}

Million tons of agricultural products are available globally, being the most underutilized abundant bio-source in the world. The valorization of its polysaccharide-rich by-products is the pivotal opportunity for moving towards sustainable processes in numerous bio-economical areas (Heise et al. 2017).

Soybean is an important source of food in many countries and its production is estimated at 364.8 million tons between the 2020 and 2021 crops (FAOSTAT 2020). The oil and protein constituents of soybeans are valuable products, but the by-products generated after harvesting the grains, such as hulls and straws, receive little attention. The inappropriate disposal of large volumes of this material is one of the causes of environmental pollution (Cabrera et al. 2015).

One way to minimize waste from disposing of soybean by-products is through the reuse of straw. Soy straw is a renewable, low-cost and easy-to-handle material, as it contains high levels of polysaccharides and does not require an extensive grinding process before pretreatment. Thus, this material is an important source for the production of chemical products with economic and social interest (Cabrera et al. 2015; Martelli-Tosi et al. 2018).

Studies have shown that lignocellulosic biomasses such as soybean straw are important sources to produce cellulose nanofibers (Martelli-Tosi et al. 2018; González et al. 2019, Souza et al. 2020) and fermentable sugars (Liu et al. 2017; Qing et al. 2017, Vedovatto et al. 2021). The cellulose nanofibers can be added, even in low concentration $(<10 \%)$, to polymeric matrices to form a biodegradable film, improving the mechanical, barrier and heat resistance properties (Han et al. 2017; Martelli-Tosi et al. 2018). In addition, in the hydrolysis processes for the production of nanofibers, the remaining portion generated comprises reducing sugars, which is used as feedstock for biochemical industries and clean energy generation (Wan et al. 2011; Chandel et al. 2015).

Lignocellulosic biomasses are formed by a complex structure of interactions between cellulose and hemicellulose, surrounded by lignin. In order to separate this vegetal structure, pretreatment is used to separate the hemicelluloses and lignin (amorphous portion) from the cellulose (crystalline portion) (Cai et al. 2017). Thus, after obtaining cellulose nanofibers, the crystalline portion is subjected to a hydrolysis process, which reduces the structure and removes possible remaining portions of hemicelluloses. Reducing sugars are generated in this part of the process. (Andrade-Mahecha et al. 2015).

The pretreatment step includes chemical, physical and/or microbiological methods capable of breaking the structure of the lignocellulosic material (Pelissari et al. 2017). Several pretreatments are used for this purpose, such as high pressure, high temperature, addition of corrosive chemicals (acids or alkalis) or use of molecular rupture techniques (ultrasound, plasma, microwave, ionizing radiation and vapor explosion) (Campos et al. 2013; Meng and Ragauskas 2014; Andrade-Mahecha et al. 2015).

The hydrolysis step can be done using acid or enzymes. It involves an acid catalyst, and its conversion is swift, requiring a control of the reaction to avoid the formation of undesirable process inhibitors. The enzymatic hydrolysis is more environmentally friendly and involves the catalyst of origin which has highly specific actions to the reaction medium (Guragain et al. 2016). Usually, the commercial enzymatic cocktails use xylanases and cellulases to hydrolyze hemicelluloses and celluloses structures, respectively 
Enzymatic hydrolysis is influenced by several factors, but mainly by enzyme and substrate concentration. As the enzymatic action is directly influenced by the amount of substrate, it is necessary to analyze simultaneously the effect of these two factors on the production of nanofibers and, consequently, reducing sugars (Campos et al. 2013; Martelli-Tosi et al. 2018). One way to study the combination of these factors is through statistical methodologies that assess interactions and consequent effects. The experimental factorial design and analysis by response surface method (RSM) allow to predict the best condition for a given system. RSM consists of statistical and mathematical techniques useful for the development of this process and aims to provide an optimal response for it. Thus, a model is generated and its validity is proven by adjusting different values of variables in the specific equation generated for this model. After optimizing this model, it is possible to compare the expected theoretical values with the experimental values (Gassara et al. 2011; Rodrigues and lemma 2014).

Therefore, the main objective of this study is to investigate the production of nanofibers and reducing sugars by different enzymatic hydrolyses conditions (variation of the enzymatic activity and biomass concentration) in soybean straws that suffer different chemical pretreatments using RSM.

\section{Materials And Methods}

\subsection{Materials}

Embrapa Soja (Londrina, Brazil) provided the soybean straw. This material was washed with distilled water and dried at $50^{\circ} \mathrm{C}$ for $72 \mathrm{~h}$ in an oven with forced circulation (Q314M, Quimis, Brazil). The dried samples were then ground in a knife mill SL31 (Solab, Brazil) and sieved through 100-mesh sieves (Tyler series, $150 \mu \mathrm{m})$. Chemical reagents such as sodium hydroxide $(\mathrm{NaOH})$, hydrogen peroxide $\left(\mathrm{H}_{2} \mathrm{O}_{2}\right)$ and sodium chlorite $\left(\mathrm{NaClO}_{2}\right)$, which were used for chemical pretreatment of soybean straw, were analytical grade. Chemicals were obtained from LabSynth (Diadema, Brazil) $\left(\mathrm{NaOH}, \mathrm{NaClO}_{2}\right.$ and $\mathrm{H}_{2} \mathrm{O}_{2}$ ) and Dinâmica (Diadema, Brazil) (ethanol (PA), acetone, acetic acid $-\mathrm{CH}_{3} \mathrm{COOH}$ and magnesium sulphate pentahydrate $\left.-\mathrm{MgSO}_{4} \cdot 7 \mathrm{H}_{2} \mathrm{O}\right)$ ). The enzymatic cocktail Optimash ${ }^{\mathrm{TM}} \mathrm{VR}$ was gently supplied by DuPont Inc (Newark, USA).

\subsection{Chemical pretreatments}

The soybean straw underwent two chemical pretreatments, as presented by Martelli et al. (2017) and summarized below.

\section{Pretreatment 1 (PT1)}

the soybean straw was suspended in $5 \% \mathrm{NaOH}$ solution $(\mathrm{w} / \mathrm{v})$ at $30^{\circ} \mathrm{C}$ for $15 \mathrm{~h}$. Then, the solution was cooled (at approximately $25^{\circ} \mathrm{C}$ ) and washed with water until pH 7. For bleaching, the fibers were left under stirring at $90^{\circ} \mathrm{C}$ for $3 \mathrm{~h}$ in a $4 \%$ mixture of $\mathrm{H}_{2} \mathrm{O}_{2}$ solution $(\mathrm{w} / \mathrm{v}), 2 \% \mathrm{NaOH}$ solution $(\mathrm{w} / \mathrm{v})$ and $0.3 \% \mathrm{MgSO}_{4} \cdot 7 \mathrm{H}_{2} \mathrm{O}$ solution $(\mathrm{w} / \mathrm{v})$ as stabilizer. The solution was cooled and neutralized again. Finally, the fibers were washed with pure acetone and ethanol. The final fibers were dried in an oven with forced air circulation at $50{ }^{\circ} \mathrm{C}$ for 24 hours.

\section{Pretreatment 2 (PT2)}

similar to the PT1, except that the first step uses $17.5 \% \mathrm{NaOH}$ solution $(\mathrm{w} / \mathrm{v})$.

\subsection{Chemical composition}

The chemical composition of soybean straw has already been studied in a previous work, as reported by Martelli-Tosi et al. (2017). This same material was used in our study. Analysis of the cellulose, holocellulose (cellulose + hemicelluloses) and lignin content in soybean straw was carried out before and after each treatment. In this case, the cellulose content was carried out according to the methodology of Sun et al. (2004). The holocellulose determination was performed according to TAPPI T19 om-54 (TAPPI 1991). The lignin was determined according to TAPPI T 222 om-22 (TAPPI 1999).

\subsection{Experimental Design}

Loading [MathJax]/jax/output/CommonHTML/jax.js 
The surface-response methodology was used to study how the soybean straw concentration and the enzyme quantity (enzymatic activity) affected the production of reducing sugar and nanofibers. To this end, a $2^{2}$ central composite design ( 4 experiments +3 axial points +3 central points) was employed (Table 1). This method is described by Rodrigues and lemma (2014).

The effects of the enzymatic activity and soybean straw concentration on the production of reducing sugars in the hydrolysate and the concentration and stability of the nanofiber suspensions were analyzed using the software Statistica 7.0. The data were fitted to the second order polynomial model (Eq. 1) according to the Response Surface Methodology. Analysis of variance (ANOVA) was performed to evaluate the significance of the model obtained for each response variable at 95 or $90 \%$ confidence interval. The data were fitted to a second order equation (Eq. 1), following the response surface methodology.

$$
Y_{i}=\beta_{0}+\beta_{1} X_{1}+\beta_{2} X_{2}+\beta_{12} X_{1} X_{2}+\beta_{11} X_{1}^{2}+\beta_{22} X_{2}^{2}
$$

Where:

$Y_{i}$

response function;

\section{$\mathrm{X}_{1}, \mathrm{X}_{2}$}

coded independent variables

\section{$\beta_{0}$}

coefficient relative to the interpretation of the plane with the response axis;

\section{$\beta_{1}, \beta_{2}$}

linear coefficients estimated by the least squares method;

\section{$\beta_{11}, \beta_{22}$}

coefficient of the quadratic variables;

\section{$\beta_{12}$}

coefficient of interaction between the independent variables.

The production of nanofibers and sugars by enzymatic hydrolysis consisted in the preparation of a suspension of macerated soybean straw (pretreated by the PT1 or PT2) in acetate buffer ( $\mathrm{pH} 4.0)$ at the concentrations specified in Table 1. The suspension was then heated at $50^{\circ} \mathrm{C}$ for further addition of the commercial enzymatic cocktail Optimash ${ }^{\text {TM }}$ VR (xylanase / cellulase) provided by Dupont (USA), with optimum activity conditions: $50^{\circ} \mathrm{C}$ at $\mathrm{pH} 4.0$. The enzymatic hydrolysis occurred at $50^{\circ} \mathrm{C}$ and $\mathrm{pH} 4.0(0.05 \mathrm{M}$ phosphate 
buffer) for $42 \mathrm{~h}$. After this treatment, protein denaturation and centrifugation $\left(7000 \mathrm{rpm}, 10^{\circ} \mathrm{C}, 10 \mathrm{~min}\right)$ were performed. The supernatant was reserved to determine the reducing sugars, and the solids were resuspended in water.

Table 1

Central rotational design compound $2^{2}$ with the different enzymatic activity quantities and soybean straw pretreated concentrations.

\begin{tabular}{|lllll|}
\hline Samples & $\begin{array}{l}\text { Enzymatic Activity } \\
\text { (coded value) }\end{array}$ & $\begin{array}{l}\text { Soybean straw pretreated (coded value) } \\
\mathbf{X}_{2}{ }^{*}\end{array}$ & $\begin{array}{l}\text { Enzymatic Activity } \\
(\mathrm{CMCU})\end{array}$ & $\begin{array}{l}\text { Soybean straw pretreated } \\
\text { (g / } / 100 \mathrm{~g} \text { of suspension) }\end{array}$ \\
\hline 1 & -1 & -1 & 400 & 2 \\
\hline 2 & +1 & -1 & 800 & 2 \\
\hline 3 & -1 & +1 & 400 & 6 \\
\hline 4 & +1 & +1 & 800 & 6 \\
\hline 5 & -1.41 & 0 & 317.2 & 4 \\
\hline 6 & +1.41 & 0 & 882.8 & 4 \\
\hline 7 & 0 & -1.41 & 600 & 1.17 \\
\hline 8 & 0 & +1.41 & 600 & 6.83 \\
\hline 9 & 0 & 0 & 600 & 4 \\
\hline 10 & 0 & 0 & 600 & 4 \\
\hline 11 & 0 & 0 & 600 & 4 \\
\hline$* X_{1}$ e $X_{2}:$ coded values. & & & \\
\hline
\end{tabular}

\subsection{Determination of cellulose nanofibers}

The suspension of solids in water was mechanically treated with Ultraturrax for 5 minutes (14000 rpm) and sonication for 3 minutes (130 W, 70\% amplitude) (VCX 130PB, Sonics \& Materials, USA), according to methodology adapted by Flauzino-Neto et al. (2013). The concentration of cellulose nanofibers (CN (\%), nanofibers/100 $\mathrm{g}$ of straw) was determined in the suspension obtained after the mechanical treatment, according to Eq. 2.

$$
\mathrm{CN}(\backslash \%)=\frac{\mathrm{MS}_{\text {suspension }}(\mathrm{g} / 100 \mathrm{~g})}{\mathrm{SS}(\mathrm{g} / 100 \mathrm{~g})} \times 100
$$

2

Where:

$\mathrm{MS}_{\text {suspension }}$

Dry matter in suspension;

SS

Loading [MathJax]/jax/output/CommonHTML/jax.js he suspension indicated in Table 1, depending on the test.

Page 5/18 


\subsection{Determination of reducing sugar}

The reducing sugars that remained from enzymatic treatment in the suspension were quantified according to the 3,5-dinitrosalicylic acid (DNS) method (Nakagame et al. 2011). The reducing sugars were calculated according to a standard glucose curve.

The reducing sugars obtained in the optimal condition were analyzed according to the xylose and glucose concentrations, which were determined by high performance liquid chromatography (HPLC).

\subsection{Zeta Potential Analysis and Morphology}

The nanofiber suspension surface charge was estimated using the zeta potential from aliquots of the aqueous suspensions of nanofibers, according to the procedure described by Teixeira et al. (2011). Three measurements of each suspension were performed with the aid of Zeta Potential Analyzer (Zetasizer ZS 3600, Malvern Instruments, UK) at a detection angle of $173^{\circ}$ and wavelength of $633 \mathrm{~nm}$ at $25^{\circ} \mathrm{C}$.

Transmission electron microscopy was used to evaluate the morphology of the cellulose nanofibers obtained in the optimum condition. The samples were sonicated in an ultrasonic bath for $2 \mathrm{~min}$. A drop of the diluted suspension was deposited on a carboncoated grid and dried at room temperature for $24 \mathrm{~h}$. The grid was immersed in an aqueous solution of $1.5 \%$ uranyl acetate for $2 \mathrm{~min}$ and dried at room temperature. The dimensions of the fibers were analyzed under a JEOL transmission electron microscope (JEM $100 \mathrm{CXII}$, Tokyo, Japan) operating at $80 \mathrm{kV}$. The images were analyzed using the ImageJ analysis software (NIH, Bethesda, USA).

\section{Results And Discussion}

\subsection{Chemical composition}

The chemical composition of untreated and chemically treated soybean straw obtained by Martelli et al. (2017) are shown in Table 2.

Table 2

Chemical composition of untreated and chemically treated soybean straw (results showed by Martelli et al. 2017).

\begin{tabular}{|c|c|c|c|c|c|}
\hline \multicolumn{2}{|c|}{ Soybean straw } & Hemicellulose (\%) & $\begin{array}{l}\text { Cellulose } \\
(\%)\end{array}$ & Insoluble Lignin (\%) & Soluble Lignin (\%) \\
\hline Control & & $22.6 \pm 1.0^{a}$ & $39.8 \pm 0.6^{c}$ & $10.5 \pm 0.7^{a}$ & $2.3 \pm 0.2^{a}$ \\
\hline \multirow[t]{2}{*}{ Pretreated } & PT1 & $10.7 \pm 0.1^{\mathrm{b}}$ & $64.0 \pm 0.7^{b}$ & $3.6 \pm 0.1^{b}$ & $0.7 \pm 0.0^{\mathrm{b}}$ \\
\hline & PT2 & $9.5 \pm 1.1^{b}$ & $66.2 \pm 0.5^{a}$ & $3.5 \pm 0.1^{b}$ & $0.7 \pm 0.1^{b}$ \\
\hline
\end{tabular}

Both pretreatments produced a material with lower hemicellulose and lignin content and higher cellulose content than the control. However, PT2 yielded samples with the highest cellulose content (66.2\%).

The difference between the pretreatments consisted in the first stage (alkaline pretreatment) in relation to the alkaline solution (sodium hydroxide) concentration. This stage results in swelling, which causes physical changes in the fiber wall, facilitating thus the penetration and diffusion of the reactants in the fiber structure (Guragain et al. 2016). Sodium hydroxide effectively attacks the linkage between lignin and hemicellulose in ${ }^{2}$ lignin-carbohydrate complexes (LCC); in particular, it cleaves the ether and ester bonds in the LCC structure. During the $\mathrm{NaOH}$ pretreatment reaction, sodium hydroxide is dissociated into hydroxide ion $\left(\mathrm{OH}^{-}\right)$and sodium ion $\left(\mathrm{Na}^{+}\right)$and, as the hydroxide ion concentration increases, the rate of the hydrolysis reaction increases proportionally (Kim et al. 2015).

\subsection{Optimization from soybean straw treated by PT1 and PT2}

As shown in Table 1, the pretreated soybean straws (PT1 and PT2) were subjected to different enzymatic treatments, obtained according to DCCR $2^{2}$. In Table 3, the results of these treatments are presented. These results were: the concentration of reducing sugars, the concentration of nanofibers and the stability of the nanofibers in suspension by zeta potential.

Loading [MathJax]/jax/output/CommonHTML/jax.js

Page 6/18 
Table 3

Reducing sugar (g glucose/100 g soybean straw), concentration of nanofibers (g nanofibers/100 g soybean straw), and zeta potential of the suspension (mV) of the tests performed according to DCCR $2^{2}$ from the soybean straw pretreated (PT1: $\mathrm{NaOH} 5 \%+\mathrm{H}_{2} \mathrm{O}_{2} 4 \%$ ) or (PT2: $\mathrm{NaOH} 17.5 \%+\mathrm{H}_{2} \mathrm{O}_{2} 4 \%$ ).

\begin{tabular}{|c|c|c|c|c|c|c|c|c|}
\hline \multirow[t]{2}{*}{ Samples } & \multirow{2}{*}{$\begin{array}{l}\text { Enzymatic } \\
\text { activity } \\
\text { CMCU } \\
\left(X_{1}\right)\end{array}$} & \multirow{2}{*}{$\begin{array}{l}\text { Soybean } \\
\text { straw } \\
\text { pretreated } \\
\mathrm{g} / 100 \mathrm{~g} \\
\left(\mathrm{X}_{2}\right)\end{array}$} & \multicolumn{3}{|c|}{ Soybean straw pretreated 1 (PT1) } & \multicolumn{3}{|c|}{ Soybean straw pretreated 2 (PT2) } \\
\hline & & & $\begin{array}{l}\text { Reducing } \\
\text { sugar } \\
\text { concentration }\end{array}$ & $\begin{array}{l}\text { Nanofiber } \\
\text { concentration }\end{array}$ & $\begin{array}{l}\text { Zeta } \\
\text { potential }\end{array}$ & $\begin{array}{l}\text { Reducing } \\
\text { sugar } \\
\text { concentration }\end{array}$ & $\begin{array}{l}\text { Nanofiber } \\
\text { concentration }\end{array}$ & $\begin{array}{l}\text { Zeta } \\
\text { potential }\end{array}$ \\
\hline 1 & $400(-1)$ & $2.00(-1)$ & 12.40 & 2.75 & -23.8 & 13.99 & 1.92 & -19.7 \\
\hline 2 & $800(+1)$ & $2.00(-1)$ & 16.34 & 3.41 & -23.9 & 32.17 & 3.44 & -19.8 \\
\hline 3 & $400(-1)$ & $6.00(+1)$ & 8.76 & 4.36 & -16.4 & 12.74 & 5.08 & -14.9 \\
\hline 4 & $800(+1)$ & $6.00(+1)$ & 11.28 & 6.30 & -17.7 & 18.69 & 6.42 & -15.8 \\
\hline 5 & $317(-1.41)$ & $4.00(0)$ & 8.29 & 6.12 & -17.5 & 10.87 & 4.11 & -17.5 \\
\hline 6 & $\begin{array}{l}883(+ \\
1.41)\end{array}$ & $4.00(0)$ & 15.14 & 2.24 & -17.8 & 18.92 & 7.43 & -16.7 \\
\hline 7 & $600(0)$ & $1.17(-1.41)$ & 16.13 & 5.93 & -25.0 & 31.21 & 3.56 & -19.4 \\
\hline 8 & $600(0)$ & $\begin{array}{l}6.83(+ \\
1.41)\end{array}$ & 9.01 & 8.82 & -15.4 & 11.46 & 5.00 & -14.3 \\
\hline 9 & $600(0)$ & $4.00(0)$ & 12.50 & 6.63 & -16.4 & 14.43 & 5.01 & -17.2 \\
\hline 10 & $600(0)$ & $4.00(0)$ & 10.78 & 7.29 & -19.7 & 15.78 & 2.95 & -16.0 \\
\hline 11 & $600(0)$ & $4.00(0)$ & 10.75 & 7.12 & -18.9 & 15.97 & 3.30 & -16.8 \\
\hline
\end{tabular}

For the analysis of the dependent variables (reducing sugar, concentration of nanofibers and zeta potential of the suspensions) in response to the independent ones (enzymatic activity and soybean straw pretreated), the results were analyzed using the Pareto diagram, with $90(p=0.10)$ and $95 \%(p=0.05)$ confidence. The Pareto diagram is associated with the effects of each individual variable and its interactions. In this diagram, the absolute values of $t_{\text {calculated }}$ from the statistical analysis (also called standardized effects) provide the heights of the bars, which are arranged in descending order. The value in which $t_{\text {calculated }}$ equals $t_{\text {tabulated }}$ completes the diagram providing a significance level of $95 \%(p=0.05)$ or $90 \%(p=0.10)$ (Rodrigues and lemma 2014). Thus, the effect of each variable is as significant as the right of the red line it is $t_{\text {calculated }}>t_{\text {tabulated. }}$. All determinations for effect or model calculations were performed by residual error, since pure error is used only for calculations of the values of non-ANOVA adjustment, that is, the pure error only indicates the variation of the central points, as discussed by Rodrigues and lemma (2014).

\subsubsection{Responses for PT1}

Figure 1 shows the effects of the soybean straw pretreated with concentration and enzymatic activity on the following response variables: (a) reducing sugar, (b) concentration of nanofibers and (c) zeta potential of suspensions.

Analyzing the Pareto diagram obtained for the reducing sugars production (Fig. 1(a)), we can observe that both the linear parameters of soybean straw concentration and the enzymatic activity showed negative and positive significant effects, respectively. It means that as higher the enzyme concentration and as lower the straw concentration in the suspension, the higher the reducing sugar production. The quadratic parameter of the soybean straw concentration had a significant effect on the sugar yield at a significance level of $86.6 \%(p<0.134)$. However, there was no effect of the linear interaction between these parameters $\left(X_{1}(L) \times X_{2}(L)\right)$.

Figure 1(b) shows that only the quadratic parameter of the enzymatic activity had a significant effect on the production of nanofibers. It is noted that the increase in the number of enzyme units improves the yield of nanofibers to an optimum value. The linear parameter of the soybean straw concentration has a significant positive effect on the production of nanofibers at the $88 \%$ significance level $(p<$ 0.12). No interaction effect was observed between both variables studied. 
Concerning the stability of the suspensions of nanofibers (Fig. 1(c)), we observed that only the soybean straw concentration (linear at 95 and $90 \%$ confidence, and quadratic parameter at $90 \%$ confidence) had a significant effect on the zeta potential values. However, most of the values obtained are between $-15 \mathrm{mV}$ and $-25 \mathrm{mV}$, which is characteristic of stable suspensions.

The concentration values of reducing sugars, nanofibers and zeta potential presented in Table 3 were adjusted to the quadratic polynomial model according to DCCR 22 at $86 \%$ confidence $(p<0.14)$. Table 4 shows the regression coefficients and the analysis of variance (ANOVA) for these response variables.

Table 4

Coefficient of regression and analysis of variance (ANOVA) for the response variables: concentration of reducing sugars, nanofibers, and zeta potential of the nanofiber suspensions using the soybean straw pretreated by PT1 $\left(\mathrm{NaOH}_{5} \%+\mathrm{H}_{2} \mathrm{O}_{2} 4 \%\right)$.

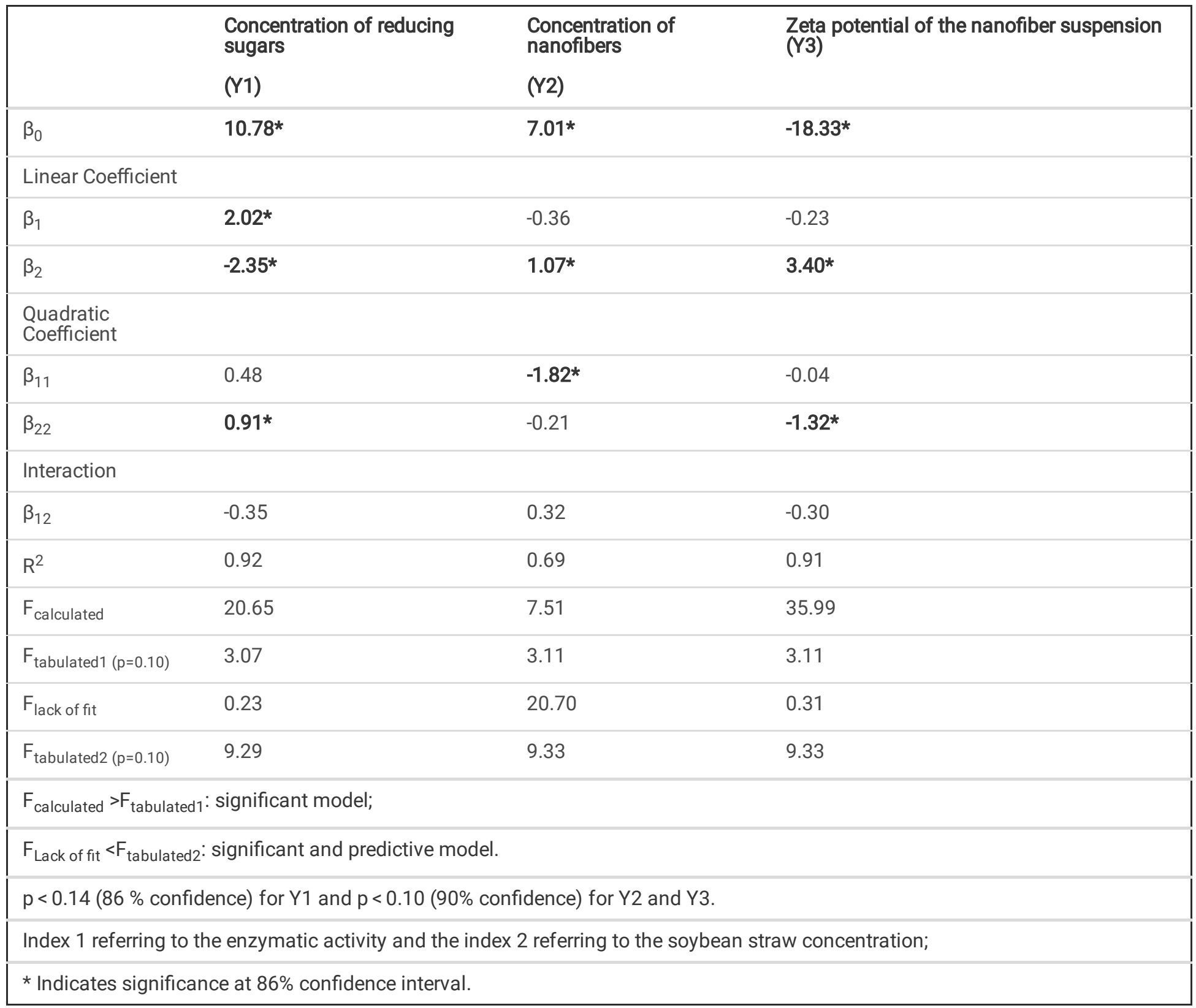

In reducing sugars production $(Y 1)$, we observed that the medium value $\left(\beta_{0}\right)$ and linear coefficients $\left(\beta_{1}\right.$ and $\left.\beta_{2}\right)$ had a significant effect at $95 \%$ confidence interval, as had already been discussed earlier by the Pareto diagram. The quadratic parameter of soybean straw concentration was significant at $86 \%$ confidence interval $(p<0.14)$. The model was significant because $F_{\text {calculated }}(20.65)$ was greater than $F_{\text {tabulated1 }}$ (3.07) and predictive, because $F_{\text {lack of fit }}(0.23)$ was lower than $F_{\text {tabulated2 }}(9.29)$. Therefore, the response surface was obtained and is shown in Fig. 2(a). As the enzymatic activity increases, the straw concentration decreases, so more reducing sugars are produced. This probably occurred due to the greater availability of the substrate to the enzymatic action. In high concentrations of straw, an inhibitory effect of enzyme activity could occur on the substrate. The catalytic action of cellulolytic enzymes can be inhibited Loading [MathJax]/jax/output/CommonHTML/jax.js the solid fraction, such as lignins and residual hemicelluloses (Kumar and Wyman 2014; 
Tibolla et al. 2014; Banerjee et al. 2017). In this condition, the enzymatic activity is higher than $800 \mathrm{CMCU}$ and soybean straw pretreated concentration is lower than $2 \mathrm{~g} / 100 \mathrm{~g}$ suspension, so it was obtained the higher reducing sugars concentration $(\sim 18 \mathrm{~g} / 100$ g soybean straw).

Concerning the production of nanofibers, we observed that the linear coefficient referring to straw concentration $\left(\beta_{2}\right)$ and the quadratic coefficient referring to the enzymatic activity $\left(\beta_{11}\right)$ had a significant effect at $86 \%$ confidence interval (Table 4 ). The model was significant, with $F_{\text {calculated }}$ (7.51) being greater than $F_{\text {tabulated1 }}$ (3.11). However, the model was not predictive $\left(F_{\text {lack of fit }}>F_{\text {tabulated2 } 2}\right)$. Therefore, the highest concentrations of nanofibers were obtained at the central points of enzymatic activity, and this concentration increased with of the straw of the suspension, as observed in tests 7-11 (Table 3). The highest concentrations were obtained using $6.83 \%$ of straw in the suspension, yielding $8.82 \mathrm{~g}$ of nanofibers $/ 100 \mathrm{~g}$ of straw.

Concerning the stability of nanofiber suspensions, evaluated with zeta potential (Y3), only linear $\left(\beta_{2}\right)$ and quadratic $\left(\beta_{22}\right)$ parameters of soybean straw concentration had significant effects at $90 \%$ confidence interval, as had already been discussed earlier by the Pareto diagram. The model was significant because $F_{\text {calculated }}$ (35.99) was greater than $F_{\text {tabulated1 }}$ (3.11) and predictive, because the $F_{\text {lack of fit }}$ (0.31) was lower than $F_{\text {tabulated2 }}$ (9.33). Therefore, the response surface was obtained, as shown in Fig. 2(b). The zeta potential varied from -18 to $-24 \mathrm{mV}$, which means that the closer to $-30 \mathrm{mV}$, the greater the stability of the nanofiber suspension (Reddy and Yang 2009). Thus, we observed that the most stable suspensions are those obtained with lower straw concentrations. The behavior was the same observed for reducing sugars. In this condition, we observed soybean straw pretreated concentration next to $1.17 \mathrm{~g} / 100 \mathrm{~g}$ suspension, enzymatic activity between 317 and $883 \mathrm{CMCU}$ and the lower zeta potential $(-24 \mathrm{mV})$. This value is next to that achieved by Banerjee et al. (2017) for reducing sugars produced from pineapple leaf waste ( $49.6 \mathrm{~g} / 100 \mathrm{~g}$ of substrate).

\subsubsection{Responses for PT2}

The effects of the soybean straw concentration and enzymatic activity in the response variables: concentration of reducing sugars, nanofibers and zeta potential of nanofiber suspensions are presented Figs. 3(a), 3(b) and (3c), respectively. Significant effects were reported at $95 \%$ confidence level $(p=0.05)$ and at $90 \%(p=0.10)$.

For the reducing sugars production (Fig. 3(a)), the linear parameters of soybean straw concentration and the enzymatic activity had negative and positive significant effects, respectively. This indicates that the higher the enzyme concentration and the lower the concentration of soybean straw in the suspension, the higher the reducing sugar production. The quadratic parameter of soybean straw concentration showed a positive significant effect on reducing sugar production at $90 \%$ significance level $(p<0.10)$. However, no effect of the linear interaction was observed between these parameters $\left(X_{1}(L) \times X_{2}(L)\right)$. This behavior was identical to that observed when using soybean straw pretreated by PT1 as raw material (Fig. 1(a)). Regardless of the previous chemical treatment, to which the straw was submitted, the effect of the variable's concentration of material and enzymatic activity had the same tendency in the response to sugar production.

For the concentration of nanofibers (Fig. 3(b)), only the linear parameter of soybean straw concentration showed a significant effect (positive) on the $95 \%$ significance level $(p<0.05)$, and the linear parameter of the enzymatic activity became significant at $90 \%(p<$ 0.10). No interaction effect was observed between the two variables studied.

In the stability of the nanofiber suspensions (Fig. 3(c)), only the soybean straw concentration (linear parameter at 95\% confidence) had a significant effect (positive) on the zeta potential values. However, most of the values obtained are between $-16 \mathrm{mV}$ and -20 $\mathrm{mV}$, as mentioned, a characteristic of stable suspensions.

The concentration values of reducing sugars, nanofibers and zeta potential values presented in Table 2 were adjusted to the quadratic polynomial model according to DCCR 22 at $90 \%$ confidence $(p<0.10)$. Table 5 shows the regression coefficients and the analysis of variance (ANOVA) for these response variables.

Loading [MathJax]/jax/output/CommonHTML/jax.js 
Table 5

Coefficient of regression and analysis of variance (ANOVA) for the response variables: concentration of reducing sugars, nanofibers, and zeta potential of the nanofiber suspensions using the soybean straw pretreated by PT2 $\left(\mathrm{NaOH} 17.5 \%+\mathrm{H}_{2} \mathrm{O}_{2} 4 \%\right)$.

\begin{tabular}{|c|c|c|c|}
\hline & $\begin{array}{l}\text { Concentration of reducing } \\
\text { sugars }\end{array}$ & $\begin{array}{l}\text { Concentration of } \\
\text { nanofibers }\end{array}$ & $\begin{array}{l}\text { Zeta potential of the nanofiber suspension } \\
\text { (Y3) }\end{array}$ \\
\hline & $(\mathrm{Y} 1)$ & $(\mathrm{Y} 2)$ & \\
\hline$\beta_{0}$ & $15.38^{*}$ & $3.75^{*}$ & $-16.66^{*}$ \\
\hline Linear coefficients & & & \\
\hline$\beta_{1}$ & $8.90 *$ & $1.89 *$ & 0.03 \\
\hline$\beta_{2}$ & $-10.68 *$ & $2.05^{\star}$ & $4.01 *$ \\
\hline $\begin{array}{l}\text { Quadratic } \\
\text { coefficients }\end{array}$ & & & \\
\hline$\beta_{11}$ & 0.14 & 1.62 & -0.73 \\
\hline$\beta_{22}$ & $6.62^{*}$ & 0.12 & -0.46 \\
\hline Interaction & & & \\
\hline$\beta_{12}$ & -6.12 & -0.09 & -0.40 \\
\hline $\mathrm{R}^{2}$ & 0.91 & 0.76 & 0.94 \\
\hline $\mathrm{F}_{\text {calculated }}$ & 12.51 & 6.13 & 87.95 \\
\hline $\mathrm{F}_{\text {tabulated1 }(\mathrm{p}=0.10)}$ & 3.07 & 3.11 & 3.36 \\
\hline$F_{\text {lack of fit }}$ & 23.46 & 1.06 & 0.97 \\
\hline $\mathrm{F}_{\text {tabulated2 }(\mathrm{p}=0.10)}$ & 9.29 & 9.33 & 9.33 \\
\hline $\mathrm{F}_{\text {calculated }}>\mathrm{F}_{\text {tabulate }}$ & significant model; & & \\
\hline $\mathrm{F}_{\text {Lack of fit }}<\mathrm{F}_{\text {tabulate }}$ & significant and predictive mo & & \\
\hline$p<0.10(90 \%$ of $c$ & dence). & & \\
\hline Index 1 referring tc & enzymatic activity and the in & 2 referring to the so & aw concentration; \\
\hline * Indicates signific & at $90 \%$ confidence interval. & & \\
\hline
\end{tabular}

In the production of reducing sugars (Y1), the medium value $\left(\beta_{0}\right)$, the linear coefficients $\left(\beta_{1}\right.$ and $\left.\beta_{2}\right)$, and quadratic coefficients of soybean straw concentration $\left(\beta_{22}\right)$ were significant at $90 \%$ confidence interval $(p<0.10)$. The model was significant, since $F_{\text {calculated }}$ (12.51) was greater than $F_{\text {tabulated1 }}$ (3.07) and not predictive, since $F_{\text {lack of fit }}(23.46)$ was greater than $F_{\text {tabulated2 }}(9.29)$. Thus, it was not possible to obtain a response surface for this variable.

In the production of nanofibers $(Y 2)$, the medium value $\left(\beta_{0}\right)$ and linear coefficients $\left(\beta_{1}\right.$ and $\left.\beta_{2}\right)$ had a significant effect at $90 \%$ confidence interval. The model was significant, since $F_{\text {calculated }}(6.13)$ was greater than $F_{\text {tabulated } 1}(3.11)$ and predictive $\left(F_{\text {lack of fit }}<\right.$

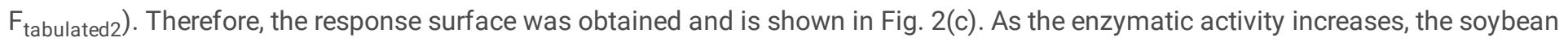
straw concentration increases, so the higher the yield of nanofibers in the suspension becomes. The greater soybean straw concentration required higher enzymatic cocktail concentration. However, no effect of the interaction was observed between these responses. The yield in nanofibers also depends on the subsequent mechanical treatment (ultraturrax and sonicator). In this case, the greater the soybean straw concentration in the suspension, the higher the action of these treatments, which also increase the yield.

Tibolla et al. (2017) also reported that the substrate concentrate had linear positive effect on the production of nanofibers from banana neel but linear neaative effect on the enzyme concentration for this parameter. Different from these studies, the nanofiber Loading [MathJax]/jax/output/CommonHTML/jax.js 
production in this condition was probably not affected by the possible products inhibited by the enzyme.

For soybean straw concentration higher than $6.00 \mathrm{~g} / 100 \mathrm{~g}$ suspension and enzymatic activity higher than $800 \mathrm{CMCU}$, higher concentration of nanofibers was obtained ( $7 \mathrm{~g} / 100 \mathrm{~g}$ soybean straw).

In the stability of the nanofiber suspensions evaluated with zeta potential (Y3), only the linear parameters ( $\beta 2)$ of soybean straw concentration had significant effect at $90 \%$ confidence interval. The model was significant $\left(F_{\text {calculated }}(87.95)>F_{\text {tabulated1 }}(3.36)\right)$ and predictive $\left(F_{\text {Lack of fit }}(0.94)<F_{\text {tabulated2 }}(9.33)\right)$. Therefore, the response surface was obtained and is shown in Fig. 2(d). The zeta potential varied from -4.3 to $-19.8 \mathrm{mV}$, being slightly lower than the values found when PT1 was used (Table 3). The material that underwent the pretreatment PT1 resulted in a sample with lower zeta potential value $(-25 \mathrm{mV})$ than that obtained from the PT2 (-20 $\mathrm{mV}$ ). This indicates that, from PT1, a colloidal suspension that resist more to aggregation and raise the degree of dispersion in the composite was obtained (Chowdary et al. 2000).

The behavior was similar between the two raw materials pretreated by PT1 or PT2, concluding the most stable suspensions are those obtained with lower soybean straw concentrations. Despite the higher alkaline solution concentration for PT2, we can observe that this condition generated a less efficient cellulose hydrolysis. It is known that insufficient hydrolysis of cellulose may result in larger particles (less surface area per unit mass) with a lower mean surface charge, favoring particle-particle interaction (Tibolla et al. 2016).

In soybean straw concentration lower than $2.00 \mathrm{~g} / 100 \mathrm{~g}$ suspension and any enzymatic activity between 317 and $883 \mathrm{CMCU}$, we obtained lower zeta potential $(\sim 19 \mathrm{mV})$, indicating a more stable colloidal suspension. These zeta potential values are higher than those obtained by Tibolla et al. (2016) for nanofiber suspensions produced from banana peel by enzymatic treatment (- 21.2 and $29.5 \mathrm{mV})$.

\subsection{Reducing sugars and cellulose nanofibers in the optimal condition}

Reducing sugars and nanofibers were by-products obtained from the soybean waste for all tested conditions. We observed higher reducing sugars concentration for higher enzymatic activity and lower soybean concentration. It was also observed higher cellulose concentration of nanofibers for higher enzymatic activity and higher soybean concentration. Thus, in general, the choice of the best condition must be made according to the production focus (sugars or nanofibers). However, the condition of the central point (points 9, 10 and 11 of Table 3) contemplates both results.

This central point (enzymatic activity: $600 \mathrm{CMCU}$ and soybean straw preteated by PT1 or PT2: $4.0 \mathrm{~g}$ soybean straw/100 g of suspension) is better suited to obtain considerable concentrations of sugars and nanofibers in a single processor system.

The mean value of reducing sugars obtained at this point by PT1 was 11.34 (g glucose/100 g soybean straw). By PT2, it was $14.30 \mathrm{~g}$ (glucose/100 g soybean straw). This behavior is in accordance with the one described by Wan et al. (2011) and Martelli-Tosi et al. (2016) and is a consequence of the increased alkaline concentration (17.5\%). For the author, this happens because a higher alkali concentration removes amorphous compounds and preserves high fractions of sugars.

Table 6 shows the amount of glucose and xylose obtained under these conditions, before and after hydrolysis. For both treatments, the addition of enzyme was effective to obtain these sugars. Significant differences were not observed in glucose uptake by PT1 and PT2. On the other hand, PT1 resulted in a higher amount of xylose than PT2. This probably occurs because the use of $17.5 \%$ alkali may have eliminated some of these sugars during pretreatment.

High concentrations of sugars are important for the subsequent fermentation process in ethanol (Xie and Liu 2015). However, the amount of reducing sugars is directly related to the raw material type and the methodology used to obtain these sugars. In wood extracts, for example, less than half of xylose $(1.18 \mathrm{~g} / \mathrm{L})$ was obtained by PT1 for the soy residues. As for glucose, for PT1 and PT2, the concentrations obtained were seven times higher than those observed for wood extract $(1.20 \mathrm{~g} / \mathrm{L})$. 
Table 6

Concentrations of glucose ( $\mathrm{g}$ glucose $/ 100 \mathrm{~g}$ solution) and

xylose ( $\mathrm{g}$ xylose/100 $\mathrm{g}$ solution) in solution of reducing

sugars.

\begin{tabular}{|lll|}
\hline & Glucose (\%) & Xylose (\%) \\
\hline PMF PT1 (5\%)B2 & 0.12 & 0.00 \\
\hline PMF PT1 (5\%) VR 630 U/g & 7.15 & 3.29 \\
\hline PMF PT2 (17.5\%) & 0.15 & 0.00 \\
\hline PMF PT2 (17.5\%) VR 630 U/g & 7.63 & 0.87 \\
\hline
\end{tabular}

In relation to cellulose nanofibers, $7.01 \mathrm{~g}$ nanofibers $/ 100 \mathrm{~g}$ soybean straw were obtained by PT1 and $3.73 \mathrm{~g}$ nanofibers/100 $\mathrm{g}$ soybean straw were obtained by PT2 in the optimal condition.

Smaller diameter determines the performance of nanofibers as reinforcing material in polymeric matrices (Heise et al. 2017). Figure 4 shows the TEM micrographs of the cellulose nanofibers obtained by the PT1 and PT2 treatments after the enzymatic activity of 600 $\mathrm{CMCU}$. Both pretreatments were effective in isolating the fibers at a nanometric scale. Nanofibers comprised a network of long entangled cellulosic filaments. Nanofibers by PT1 presented mean diameter of $9.2 \mathrm{~nm}$ and lengths of $237 \mathrm{~nm}$, while nanofibers by PT2 showed mean diameter of $9.3 \mathrm{~nm}$ and lengths of $159 \mathrm{~nm}$. The length of nanofibers by PT2 were smaller due to the type of treatment. A more severe treatment with $\mathrm{NaOH} 17.5 \%$ facilitated the enzymatic action on the amorphous region, so that lignin and hemicelluloses were removed more easily from the structure in this region.

The morphology of nanofibers depends on the material origin. However, similar dimensions were found in the literature for other raw materials: banana peel (7.6-10.9 nm) (Tibolla et al. 2016), bagasse pulp (9-25 nm) (Mathew and Hassan 2010) and rice straw (12$35 \mathrm{~nm}$ ) (Abe and Yano 2009)

\section{Conclusion}

The Central Compound Design Rotational $2^{2}$ allowed us to observe the enzymatic activity and the biomass concentration effect on the production of reducing sugars and nanofibers in two types of pretreated soybean straw (PT1 and PT2). For both, higher concentrations of the enzyme favored the reducing sugars production. However, the increase in the soybean straw pretreated concentration decreased the production of reducing sugars.

Regarding nanofibers production, the two soybean straws pretreated suffered different effects. For the PT1, the increase in enzymatic activity disfavored the nanofibers production, while for PT2 the soybean straw concentration showed positive effect on $p=0.05$, and on $p=0.10$; the enzymatic activity and soybean straw concentration showed positive effect on nanofiber production. This indicates that the initial biomass type used as substrate implies in different results in enzymatic hydrolysis.

About the stability of the suspensions, the most stable suspensions were those obtained with lower soybean straw pretreated concentration for both conditions (PT1 and PT2).

In all tests, it was possible to obtain suspensions of reducing sugars and cellulose nanofibers. However, the central point of planning is what favors the production of both simultaneously. At this point, sugars and nanofibers are produced in considerable concentrations.

Therefore, this study concluded that it is possible to use small amounts of soybean straw for a good and efficient production of cellulose nanofibers and reducing sugars.

\section{Declarations}

\section{Acknowledgments}

The São Paulo Research Foundation - FAPESP (grant number 2016/18788-1 and 2012/22157-2) supported this study. The authors gratefully acknowledge the National Council for Scientific and Technological Development (CNPq) for the fellowship granted to N.S, Loading [MathJax]/jax/output/CommonHTML/jax.js

Page $12 / 18$ 
and the Coordination for the Improvement of Higher Education Personnel (CAPES) for the doctoral fellowship of B.M.

Funding: The São Paulo Research Foundation - FAPESP (grant number 2016/18788-1 and 2012/22157-2), the National Council for Scientific and Technological Development - CNPq (fellowship of Silva, N. C.), and the Coordination for the Improvement of Higher Education Personnel - CAPES (doctoral fellowship of B.M) supported this study.

Conflicts of interest/Competing interests: All authors declare that there are no conflicts of interest in this work.

Availability of data and material: All authors declare that the data published here are original and have not been previously published in other journals.

Code availability: Not applicable for that section.

Authors' contributions: Silva, N. C.: Conceptualization, Investigation, Methodology, Formal analysis, Project administration, Data curation, Writing - original draft. Esposto, B. S.: Conceptualization, Investigation, Methodology, Formal analysis, Project administration, Data curation. Maniglia, B.C.Conceptualization, Investigation, Methodology, Formal analysis, Project administration, Data curation. Tapia-Blácido, D.R.: Conceptualization, Investigation, Methodology, Formal analysis, Project administration, Data curation. Martelli-Tosi, M.:Conceptualization, Investigation, Methodology, Formal analysis, Project administration, Data curation, Writing original draft.

Ethics approval: Not applicable for that section.

Consent to participate: All authors declare to have actively participated in the development of this work.

Consent for publication: All authors declare that they are in agreement with the publication of this work.

\section{References}

1. Abe K, Yano H. (2009) Comparison of the characteristics of cellulose microfibril aggregates of wood, rice straw and potato tuber. Cellulose, 16(6):1017-1023. https://doi.org/10.1007/s10570-009-9334-9

2. Andrade-Mahecha M M, Pelissari F M et al (2015) Achira as a source of biodegradable materials: Isolation and characterization of nanofibers. Carbohydrate Polymers, 123:406-415. https://doi.org/10.1016/j.carbpol.2015.01.027

3. Banerjee R, Chintagunta, A D et al (2017) A cleaner and eco-friendly bioprocess for enhancing reducing sugar production from pineapple leaf waste. Journal of Cleaner Production, 149:387-395. https://doi.org/10.1016/j.jclepro.2017.02.088

4. Cabrera E, Muñoz M J et al (2015) Comparison of industrially viable pretreatments to enhance soybean straw biodegradability. Bioresource Technology, 194:1-6. https://doi.org/10.1016/j.biortech.2015.06.090

5. Cai J, He Y et al (2017) Review of physicochemical properties and analytical characterization of lignocellulosic biomass. Renewable and Sustainable Energy Reviews, 76:309-322. https://doi.org/10.1016/j.rser.2017.03.072

6. Campos A, Correa A. C et al (2013) Obtaining nanofibers from curauá and sugarcane bagasse fibers using enzymatic hydrolysis followed by sonication. Cellulose, 20(3):1491-1500. https://doi.org/10.1007/s10570-013-9909-3

7. Chandel A K, Gonçalves B C M et al (2015) Biodelignification of lignocellulose substrates: An intrinsic and sustainable pretreatment strategy for clean energy production. Critical Reviews in Biotechnology, 35(3):281-293. https://doi.org/10.3109/07388551.2013.841638

8. Chowdary G V, Hari Krishna S et al (2000) Optimization of enzymatic hydrolysis of mango kernel starch by response surface methodology. Bioprocess Engineering, 23(6):681-685. https://doi.org/10.1007/s004490000220

9. FAOSTAT. Food and Agriculture Organization of United Nations (2020). Production, Crops, Soybeans. <http://faostat.fao.org/> Accessed on March 31.

10. Flauzino-Neto W P, Silvério H A et al (2013) Extraction and characterization of cellulose nanocrystals from agro-industrial residue Soy hulls. Industrial Crops and Products, 42(1):480-488. https://doi.org/10.1016/j.indcrop.2012.06.041

11. Gassara F, Brar S K et al (2011) Parameter optimization for production of ligninolytic enzymes using agro-industrial wastes by response surface method. Biotechnology and Bioprocess Engineering, 16(2):343-351. https://doi.org/10.1007/s12257-010-0264-

Loading [MathJax]/jax/output/CommonHTML/jax.js

Page 13/18 
12. González A, Gastelú G et al (2019) Preparation and characterization of soy protein films reinforced with cellulose nanofibers obtained from soybean by-products. Food Hydrocolloids, 89:758-764. https://doi.org/10.1016/j.foodhyd.2018.11.051

13. Guragain Y N, Wang D et al (2016) Appropriate biorefining strategies for multiple feedstocks: Critical evaluation for pretreatment methods, and hydrolysis with high solids loading. Renewable Energy, 96:832-842. https://doi.org/10.1016/j.renene.2016.04.099

14. Han S Y, Park C (2017) Effect of Enzymatic Hydrolysis of Cellulose Nanofibers on the Properties of Poly (Vinyl Alcohol) Nanocomposite. Journal of Forest and Environmental Science, 33(2):154-159. https://doi.org/10.7747/JFES.2017.33.2.154

15. Heise K, Rossberg C et al (2017) Impact of pre-treatments on properties of lignocelluloses and their accessibility for a subsequent carboxymethylation. Carbohydrate Polymers, 161:82-89. https://doi.org/10.1016/j.carbpol.2016.12.066

16. Kim J H, Shim B S et al (2015) Review of nanocellulose for sustainable future materials. International Journal of Precision Engineering and Manufacturing - Green Technology, 2(2):197-213. https://doi.org/10.1007/s40684-015-0024-9

17. Kumar R, Wyman C E (2014) Strong cellulase inhibition by Mannan polysaccharides in cellulose conversion to sugars. Biotechnology and Bioengineering, 111(7):1341-1353. https://doi.org/10.1002/bit.25218

18. Liu Y, Guo L (2017) Irradiation pretreatment facilitates the achievement of high total sugars concentration from lignocellulose biomass. Bioresource Technology, 232:270-277. https://doi.org/10.1016/j.biortech.2017.01.061

19. Martelli-Tosi M, Assis O B G et al (2017) Chemical treatment and characterization of soybean straw and soybean protein isolate/straw composite films. Carbohydrate Polymers, 157:512-520. https://doi.org/10.1016/j.carbpol.2016.10.013

20. Martelli-Tosi M, Masson M M et al (2018) Soybean straw nanocellulose produced by enzymatic or acid treatment as a reinforcing filler in soy protein isolate films. Carbohydrate Polymers, 198:61-68. https://doi.org/10.1016/j.carbpol.2018.06.053

21. Martelli-Tosi, M, Torricillas M S M et al (2016) Using Commercial Enzymes to Produce Cellulose Nanofibers from Soybean Straw. Journal of Nanomaterials, 1-10. https://doi.org/10.1155/2016/8106814

22. Mathew A P, Hassan E A (2010) Effect of pretreatment of bagasse pulp on properties of isolated nanofibers and nanopaper sheets. Wood And Fiber Science, 42(3):1-15.

23. Meng X, Ragauskas A J (2014) Recent advances in understanding the role of cellulose accessibility in enzymatic hydrolysis of lignocellulosic substrates. Current Opinion in Biotechnology, 27:150-158. https://doi.org/10.1016/j.copbio.2014.01.014

24. Nakagame S, Chandra R P et al (2011) The isolation, characterization and effect of lignin isolated from steam pretreated Douglas-fir on the enzymatic hydrolysis of cellulose. Bioresource Technology, 102(6):4507-4517. https://doi.org/10.1016/j.biortech.2010.12.082

25. Pelissari F M, Andrade-Mahecha M M et al (2017) Nanocomposites based on banana starch reinforced with cellulose nanofibers isolated from banana peels. Journal of Colloid and Interface Science, 505:154-167. https://doi.org/10.1016/j.jcis.2017.05.106

26. Qing Q, Guo Q et al (2017) Comparison of alkaline and acid pretreatments for enzymatic hydrolysis of soybean hull and soybean straw to produce fermentable sugars. Industrial Crops and Products, 109:391-397.

https://doi.org/10.1016/j.indcrop.2017.08.051

27. Reddy N, Yang Y (2009) Natural cellulose fibers from soybean straw. Bioresource Technology, 100(14):3593-3598. https://doi.org/10.1016/j.biortech.2008.09.063

28. Rodrigues M I, lemma A F. (2014) Planejamento de experimentos e otimização de processos: uma estratégia seqüêncial de planejamentos. Campinas: Editora Casa do Pão.

29. Souza A G, Santos D F et al (2020) Innovative process for obtaining modified nanocellulose from soybean straw. International Journal of Biological Macromolecules, 165:1803 - 1812. https://doi.org/10.1016/j.ijbiomac.2020.10.036

30. Sun J X, Sun X F et al (2004) Isolation and characterization of cellulose from sugarcane bagasse. Polymer Degradation and Stability, 84(2):331-339. https://doi.org/10.1016/j.polymdegradstab.2004.02.008

31. TAPPI (1991) TAPPI Standard. - Method T19 om-54. TAPPI Test Methods.

32. TAPPI (1999) TAPPI Standard. - Method T222 om-88. TAPPI Test Methods.

33. Teixeira E M, Bondancia $\mathrm{T} J$ et al (2011) Sugarcane bagasse whiskers: Extraction and characterizations. Industrial Crops and Products, 33(1):63-66. https://doi.org/10.1016/j.indcrop.2010.08.009

34. Tibolla H, Pelissari F M et al (2014) Cellulose nanofibers produced from banana peel by chemical and enzymatic treatment. LWT Food Science and Technology, 59:1311-1318. https://doi.org/10.1016/j.lwt.2014.04.011

Loading [MathJax]/jax/output/CommonHTML/jax.js

Page $14 / 18$ 
35. Tibolla H, Pelissari F M et al (2017) Cellulose nanofibers produced from banana peel by enzymatic treatment: Study of process conditions. Industrial Crops and Products, 95:664-674. https://doi.org/10.1016/j.indcrop.2016.11.035

36. Vedovatto F, Ugalde $\mathrm{G}$ et al (2021) Subcritical water hydrolysis of soybean residues for obtaining fermentable sugars. The Journal of Supercritical Fluids, 167:105043. https://doi.org/10.1016/j.supflu.2020.105043

37. Wan C, Zhou Y et al (2011) Liquid hot water and alkaline pretreatment of soybean straw for improving cellulose digestibility. Bioresource Technology, 102(10):6254-6259. https://doi.org/10.1016/j.biortech.2011.02.075

38. Xie Y, Liu S (2015) Purification and concentration of paulownia hot water wood extracts with nanofiltration. Separation and Purification Technology, 156:848-855. https://doi.org/10.1016/j.seppur.2015.11.012

\section{Figures}
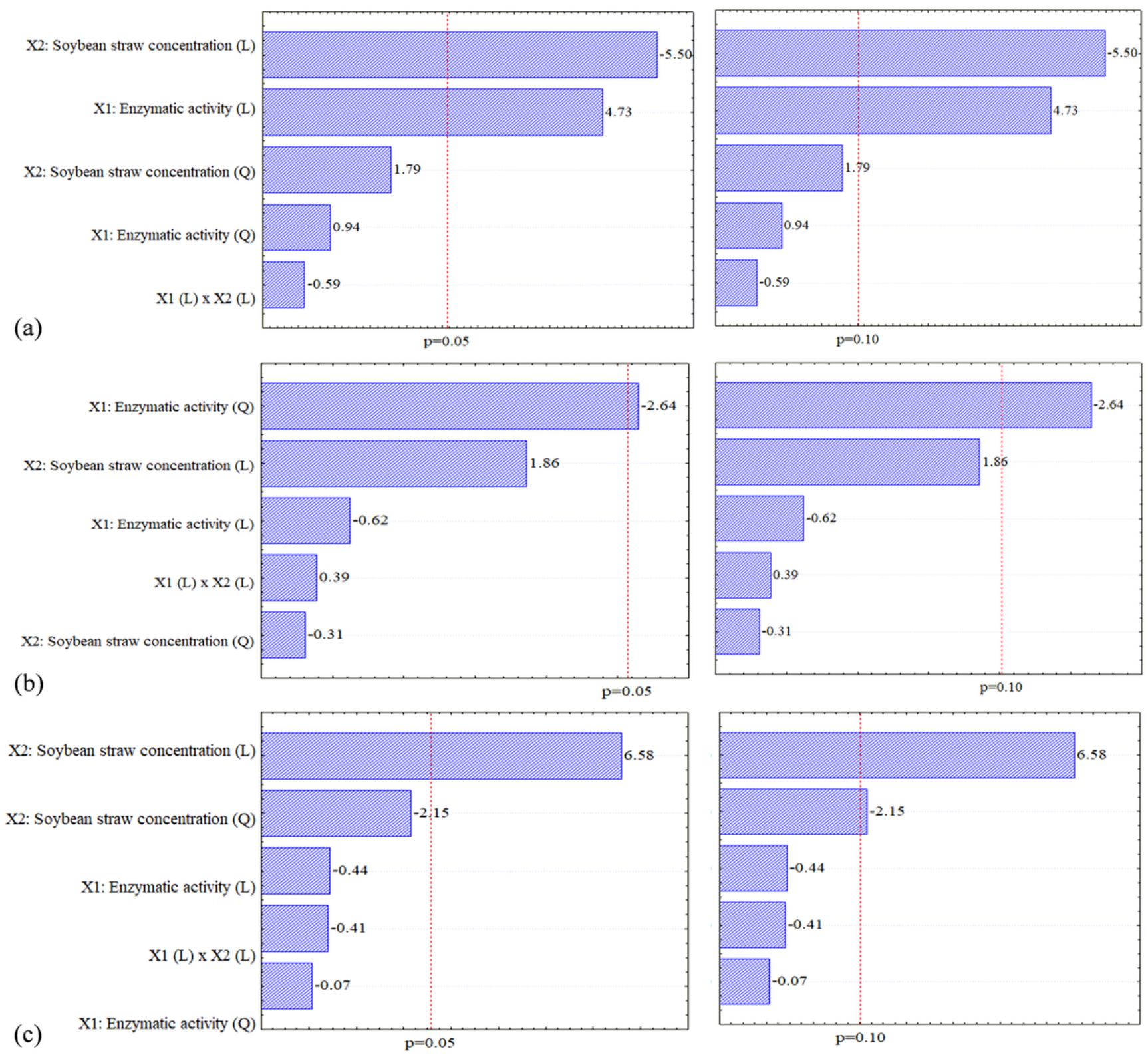

\section{Figure 1}

Concentration of (a) reducing sugars (b), nanofibers, and (c) zeta potential of the suspensionsusing as raw material the soybean straw pretreated by PT1. The effects at two significance levels were found for each variable: $95 \%$ confidence $(p=0.05)$ or $90 \%$ confidence $(p=0.10)$. 
(a)

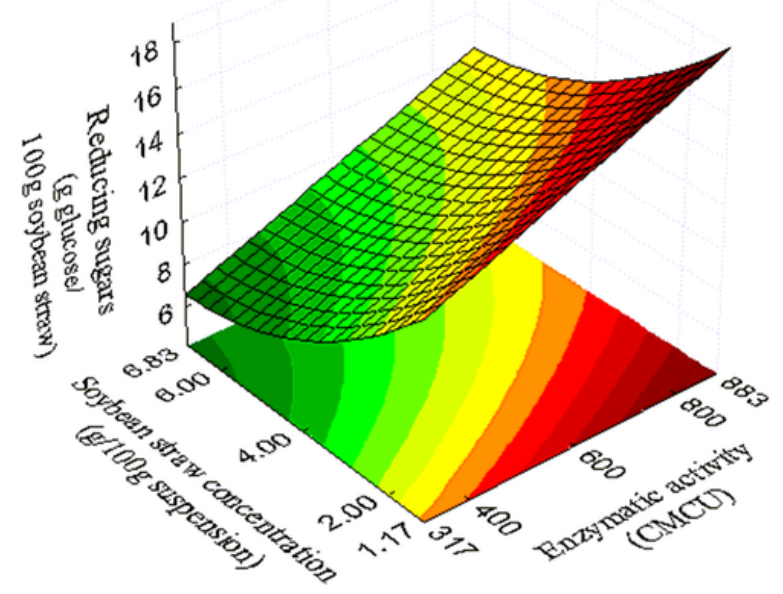

(c)

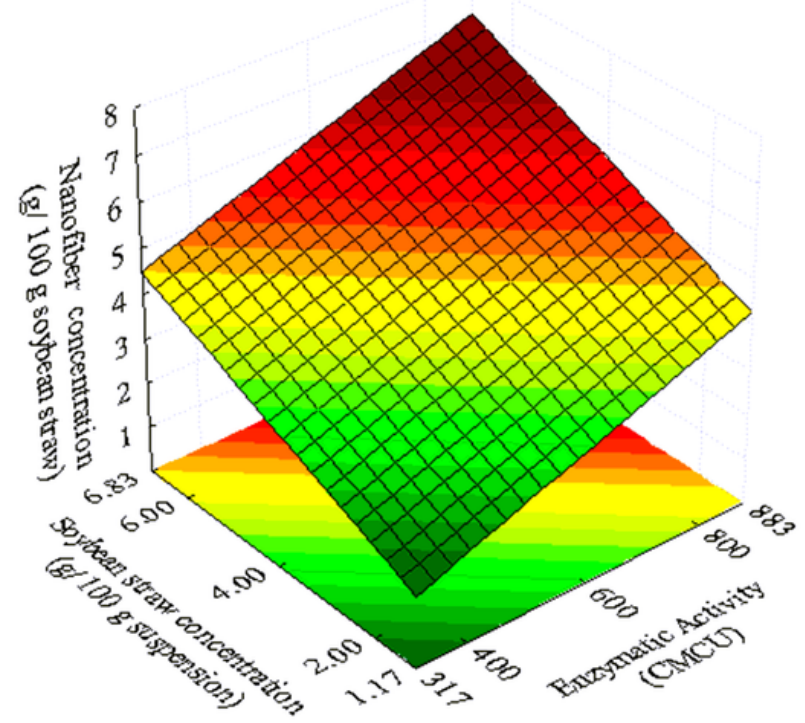

(b)

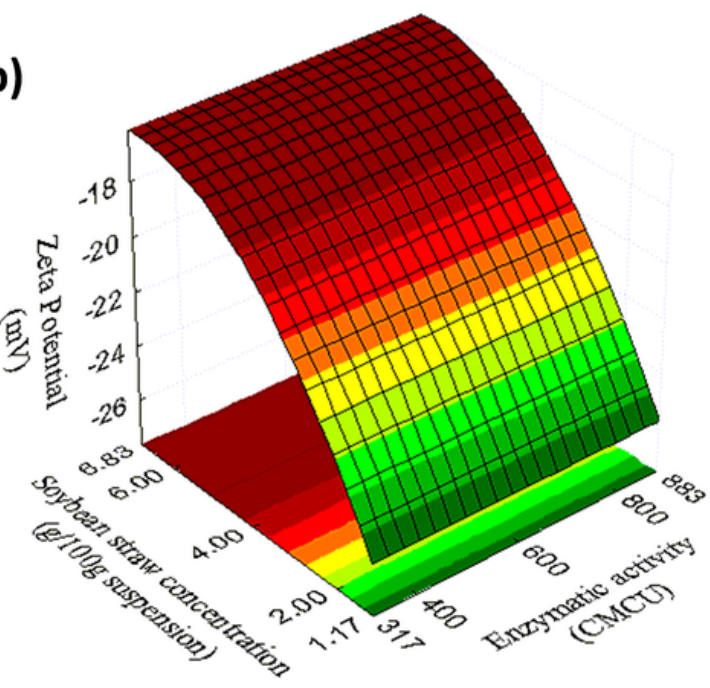

(d)

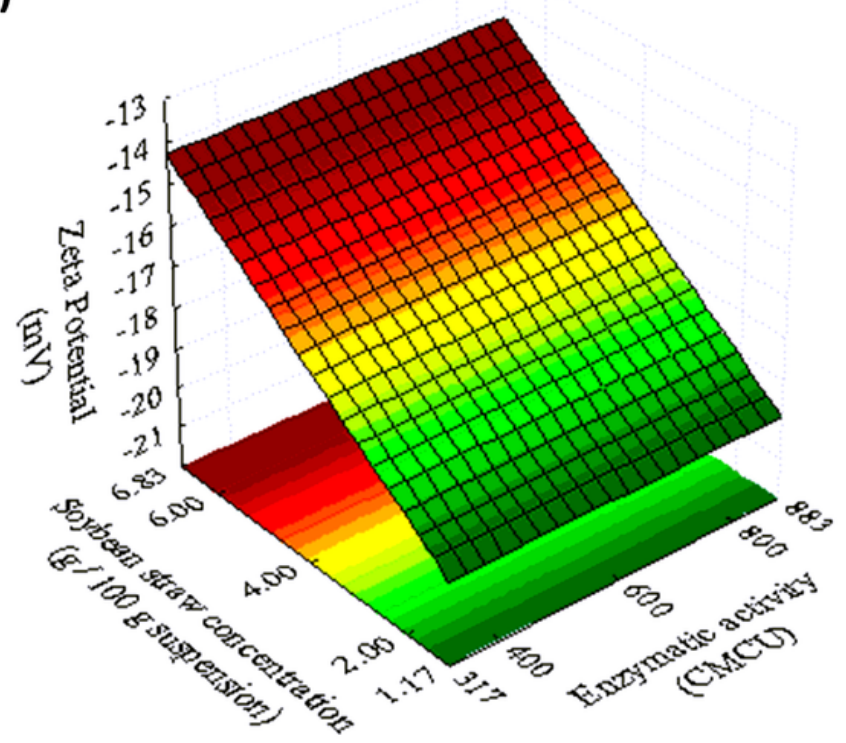

Figure 2

Response surfaces for PT1: (a) concentration of reducing sugars, obtained with a 14\% significance level; and (b) zeta potential values $(\mathrm{mV})$ of the nanofiber suspensions, obtained with a 10\% significance level. Response surfaces for PT2: (c) concentration of nanofibers ( $\mathrm{g}$ of nanofibers / $100 \mathrm{~g}$ of straw); and (d) zeta potential values $(\mathrm{mV})$ of the nanofiber suspensions, both were obtained with a $10 \%$ significance level. 
$\mathrm{X} 1$ : Soybean straw concentration $(\mathrm{L})$

$\mathrm{X} 2$ : Enzymatic activity (L)

X1: Soybean straw concentration (Q)

(a)

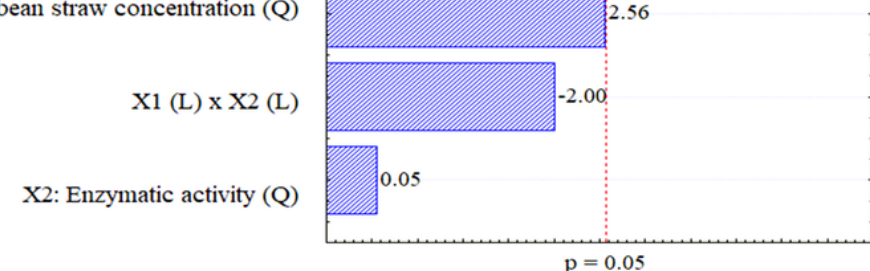

$\mathrm{X} 2$ : Soybean straw concentration (L)

$\mathrm{X} 1$ : Enzymatic activity (L)

$\mathrm{X} 1$ : Enzymatic activity $(\mathrm{Q})$

$\mathrm{X} 2$ : Soybean straw concentration $(\mathrm{Q})$

(b)

$\mathrm{X} 1(\mathrm{~L}) \times \mathrm{X} 2(\mathrm{~L})$
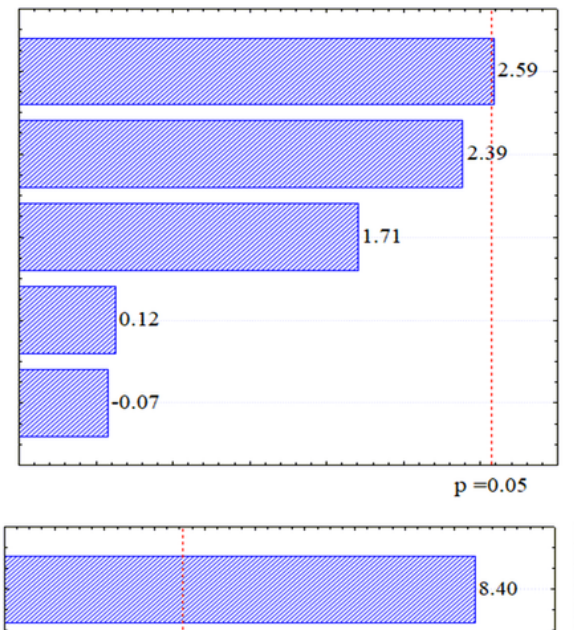

$\mathrm{X} 1$ : Enzymatic activity (Q)

$\mathrm{X} 2$ : Soybean straw concentration $(\mathrm{Q})$

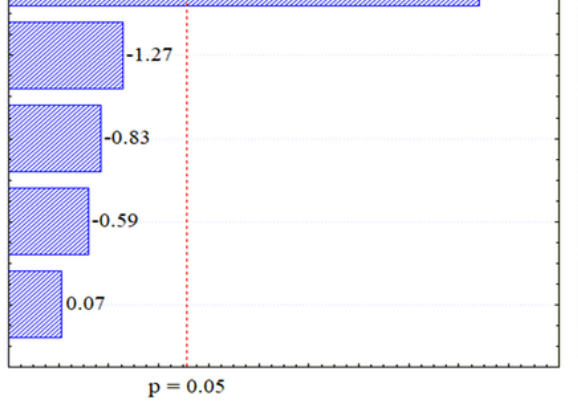

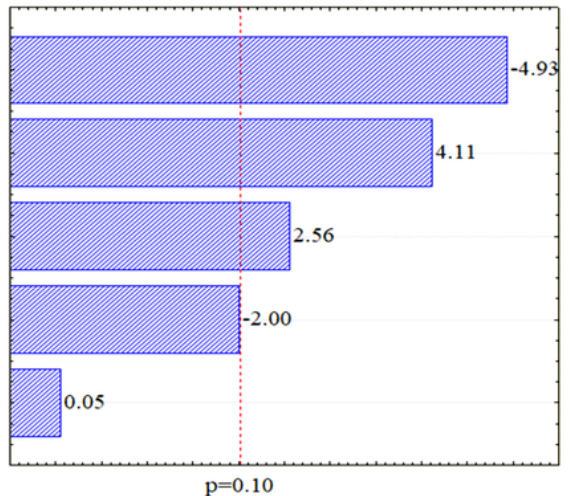

$\mathrm{p}=0.10$
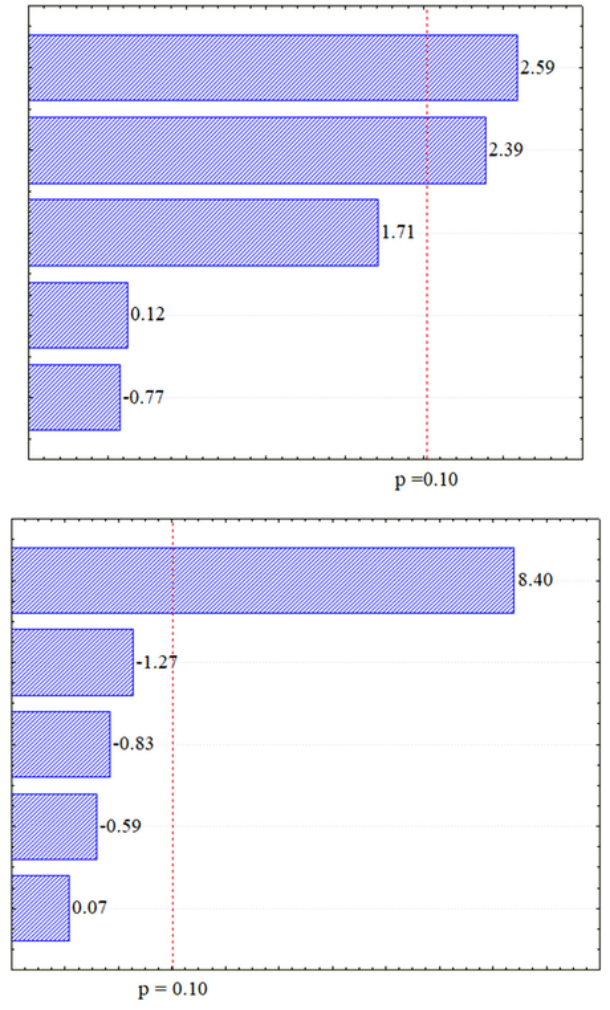

\section{Figure 3}

Concentration of (a) reducing sugars (b), nanofibers, and (c) zeta potential of the suspensions using as raw material the soybean straw pretreated by PT2. The effects at two significance levels were found for each variable: $95 \%$ confidence $(p=0.05)$ or $90 \%$ confidence $(p=0.10)$. 


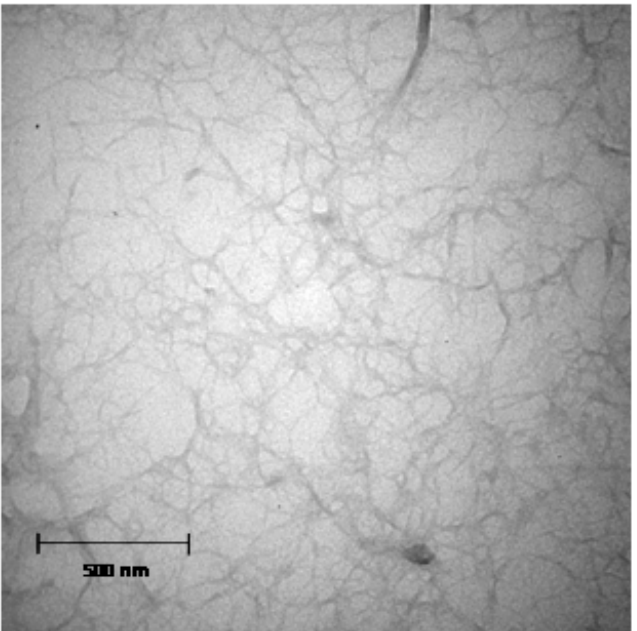

(a)

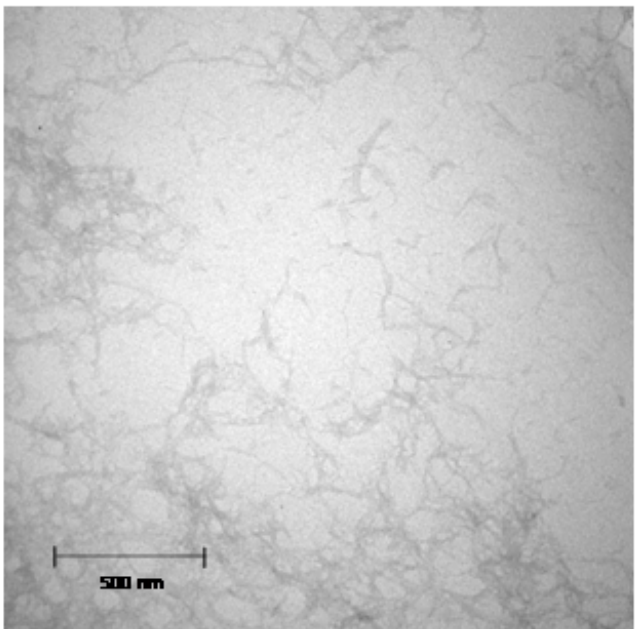

(b)

Figure 4

TEM micrographs of cellulose nanofibers by (a) PT1 and (b) PT2 after the enzymatic activity of 600 CMCU. 